\title{
Rekonseptulisasi Penegakkan Hukum Terhadap Pelaku Dan Korban Undang-Undang Informasi Dan Transaksi Elektronik Berbasis Restorative Justice
}

\author{
Zul Afiff Senen \\ Magister Hukum Fakultas Hukum Universitas Islam Indonesia Yogyakarta Indonesia \\ Jln. Cik Di Tiro No. 1 Yogyakarta Indonesia \\ zulafifff@gmail.com
}

\begin{abstract}
Presently, Indonesia has a tendency to execute over-criminalization. One of which is in the settlement of legal cases over Law Number 19 of 2016 on Amendments to Law Number 11 of 2008 on Information and Electronic Transactions (ITE Law) which prioritizes criminal sanctions. Whereas in its content, the Law provides administrative sanctions, so that the ultimum remidium must be carried out by law enforcement officials. The author formulates two problems, namely first, what is the restotative justice model at the level of investigation, prosecution, and trial?; second, how is the reconceptualization of the application of restorative justice to the perpetrators and victims of the ITE Law? The research method used is a normative juridical method with a statutory and conceptual approaches and uses secondary data sources, in the form of primary, secondary, and tertiary legal materials. The results of this study conclude that first, at the level of restorative justice through material and formal investigations, the level of prosecution through the peaceful means and efforts by paying attention to the court supporting devices. Second, while at the trial level through law enforcement officers who are able to sort out and support efforts on restorative justice to produce a fair legal decisions. Second, reconceptualization of restorative justice in law enforcement of the ITE Law is through concepts of moro, dats and virtual justice.
\end{abstract}

Key Words: Criminalization; ITE law; restorative justice

\begin{abstract}
Abstrak
Dewasa ini, Indonesia mengalami kecenderungan over kriminalisasi. Salah satunya terdapat dalam penyelesaian kasus hukum atas Undang-Undang Nomor 19 Tahun 2016 tentang Perubahan Atas Undang-Undang Nomor 11 Tahun 2008 tentang Informasi dan Transaksi Elektronik (UU ITE) yang lebih mengedepankan sanksi pidana. Padahal dalam muatannya, UU ini mengandung sanksi administratif, sehingga ultimum remidium harus dilakukan oleh aparat penegak hukum. Penulis merumuskan dua masalah, yaitu pertama, bagaimanakah model restotative justice pada tingkat penyidikan, penuntutan, dan pengadilan?; kedua, bagaimanakah rekonseptualisasi terhadap penerapan restorative justice pada pelaku dan korban tindak pidana UU ITE?. Metode penelian yang digunakan adalah metode yuridis normatif dengan pendekatan peraturan perundang-undangan dan konseptual serta menggunakan sumber data sekunder, berupa bahan hukum primer, sekunder, dan tersier. Hasil dari penelitian ini menyimpulkan bahwa pertama, di tingkat penyidikan restorative justice melalui materiil dan formil, tingkat penuntutan melalui proses dan upaya perdamaian dengan memperhatikan perangkat pendukung sidang. Kedua, tingkat pengadilan melalui aparat penegak hukum yang dapat memilah dan mendukung dalam upaya restorative justice, sehingga menghasilkan putusan hukum yang berkeadilan. Kedua, rekonseptual restorative justice dalam penegakan hukum UU ITE melalui moro konsep, dats konsep, dan virtual justice consept.
\end{abstract}

Kata-kata Kunci: Pemidanaan; UU ITE; restorative justice 


\section{Pendahuluan}

Dewasa ini, Indonesia mengalami kecenderungan over kriminalisasi, dimana setiap pembuatan undang-undang diberi muatan pidana dengan alasan agar norma di dalamnya lebih ditaati. Barda Nawawi Arief mengartikan, overcriminalization sebagai banyak atau melimpahnya jumlah kejahatan dan perbuatan-perbuatan yang dikriminalisasi. Overcriminalization timbul bila proses kriminalisasi yang berlangsung secara terus menerus tanpa didasarkan pada penilaian yang teruji dan tanpa suatu evaluasi mengenai pengaruhnya terhadap keseluruhan sistem. Ragam bentuk overcriminalization dalam peraturan undangan-undang pidana meliputi:

\section{Rekriminalisasi Delik (Overlapping Crimes)}

Rumusan delik yang masuk dalam kategori overlapping crimes terdapat dalam Pasal 108 jo Pasal 56 ayat (1) UU Perkebunan dan Pasal 108 jo Pasal 69 ayat (1) huruf h UU PPLH. Substansi kedua pasal di atas adalah sama-sama melarang membakar lahan. Lahan yang dimaksud lahan dalam UU Perkebunan adalah lahan perkebunan, sedangkan lahan dalam UU PPLH lahan apapun termasuk lahan perkebunan. Meskipun objek pembakaran dalam UU Perkebunan dibatasi pada lahan perkebunan, tapi substansi pasal tersebut sebenarnya sama dengan substansi dalam Pasal 108 UU PPLH. Oleh karena itu, ada satu perbuatan yang sama yang diatur di dalam dua undang-undang yang sama-sama terkait lingkungan hidup. Pengaturan delik yang demikian menimbulkan overcriminalization dalam bentuk overlapping crimes, yaitu satu perbuatan yang sama dilarang dan diatur dalam dua undang-undang yang berbeda.

\section{Rumusan Delik yang Tidak Jelas Arti dan Ruang Lingkupnya (Lex Certa)}

Rumusan delik yang yang tidak memenuhi prinsip lex certa terdapat Pasal 162 jo Pasal 136 ayat (2) UU Minerba.

1. Perbuatan yang dikriminalisasi murni sebagai pelanggaran administratif Perbuatan yang dikriminalisasi murni sebagai pelanggaran administratif terdapat dalam Pasal 105 UU Perkebunan.

2. Beratnya pidana tidak mencerminkan seriusitas delik (disproportionate sentence).

Beratnya pidana tidak mencerminkan keseriusan delik (disproportionate sentence) terdapat dalam Pasal 98 ayat (1) dan 112 yang merupakan delik materiil dibandingkan dengan Pasal 106 dan Pasal 107 UU PPLH yang dirumuskan 
sebagai delik formil. Ancaman pidana terhadap delik formil justru lebih berat daripada delik materiil. ${ }^{1}$

Hal itu diperparah dengan kenyataan bahwa ancaman pidananya lebih banyak menggunakan pidana terhadap kemerdekaan seperti penjara dan kurungan. Meskipun ada ancaman pidana denda, namun formulasi sanksinya kumulatif (penjara dan denda). Menurut ahli hukum pidana Undang-Undang Nomor 19 Tahun 2016 tentang Perubahan Atas Undang-Undang Nomor 11 Tahun 2008 tentang Informasi dan Transaksi Elektronik (UU ITE) bersifat administrasi. Namun, dalam realitanya terdapat pembebanan atas sanksi yang diterima oleh pelaku tindak pidana melalui hukuman pidana atau kurungan. Keadaan ini menjadi beban bagi subsistem peradilan pidana yang berada di hilirnya yakni Lembaga Pemasyarakatan.

Dodot menyampaikan data terbaru ada sebanyak 200 ribu lebih warga binaan yang berada di lapas dan rutan. Sementara kapasitas lapas dan rutan sendiri hanya diperuntukkan menampung sekitar 100 ribu lebih orang. Data per 14 Februari 2021 ini terdapat 252.384 orang warga binaan pemasyarakatan terdiri dari narapidana dan tahanan. Kapasitas lembaga pemasyarakatan dan rumah tahanan negara kita saat ini itu hanya 135.704 orang. ${ }^{2}$ Hal ini memperlihatkan bahwa hampir semua sistem peradilan pidana telah memasukkan mekanisme untuk menghindarkan setiap kasus pidana harus berujung di pengadilan sebagian besar sistem peradilan pidana tidak akan dapat berfungsi dengan baik, karena terlalu keberatan beban jumlah kasus. ${ }^{3}$

Penjara telah mendarah daging di dalam diri aparat penegak hukum dan pihak yang merasa dirugikan atas suatu perbuatan yang ditimbulkan. Sebagaian masyarakat menilai hukum sebagai instrumen pembalasan, bukan sebagai instrumen pembinaan atas suatu perbuatan yang ditimbulkan dan si pelaku menginsyafi akan hal tersebut. Bahkan aparat penegak hukum lebih fokus kepada kondisi korban, namun sedikit yang fokus terhadap pembinaan dari si pelaku tersebut, seperti kasus-kasus yang ada terutama di bidang informasi dan transaksi elektronik ini lebih banyak keterpihakan kepada korban, namun surut pandangan terhadap pembinaan kepada pelaku.

Dalam perkembangaannya, Indonesia sendiripun telah mengenal adanya restorative justice yang lebih mengedepankan mediasi antara pelaku dan korban. ${ }^{4}$

${ }^{1}$ Mahrus Ali, "Overcriminalization dalam Perundang-Undangan di Indonesia", Jurnal Hukum Ius Quia Iustum, Vol. 25, No. 3, 2018, hlm. 467.

2 Detik.com, https://news.detik.com/berita/d-5374503/ditjen-pas-warga-binaan-252384-orangkapasitas-lapas-rutan-hanya-135704, di akses 24 Mei 2021, pukul 17.35 Wib.

${ }^{3}$ Febby Mutiara Nelson, "Due Process Model dan Restorative Justice Di Indonesia: Suatu Telaah Konseptual“, Jurnal Hukum Pidana \& Kriminologi, Volume 1, No. 1 Oktober 2020, hlm. 93.

${ }^{4}$ Ibid., hlm. 94 
Jika berbicara mengenai sanksi pemidanaan tentunya tak akan lepas dari tujuan dan fungsi adanya hukum pidana yakni sebagai pelindung kepentingan masyarakat maupun perseorangan dari tindakan-tindakan yang dinilai tidak menyenangkan akibat adanya suatu pelanggaran yang dilakukan oleh seseorang terhadap orang lain dan fungsi dari hukum pidana haruslah diletakkan sebagai upaya terakhir dalam suatu proses pemidanaan (ultimum remidium) bukan sebagai upaya awal (primum remidium). ${ }^{5}$

Membaca uraian di atas, penulis tertarik membuat suatu tulisan ilmiah yang berjudul "Rekonseptulisasi Penegakkan Hukum terhadap Pelaku dan Korban Undang-Undang Informasi dan Transaksi Elektronik Berbasis Restoratif Justice".

\section{Rumusan Masalah}

1. Bagaimanakah model restotative justice pada tingkat penyidikan, penuntutan, dan pengadilan?

2. Bagaimanakah rekonseptualisasi terhadap penerapan restorative justice pada pelaku dan korban tindak pidana UU ITE?

\section{Metode Penelitian}

Metode penelitian yang digunakan adalah metode yuridis normatif dengan pendekatan peraturan perundang-undangan dan analitis, sedangkan pengumpulan data melalui studi kepustakaan dengan pendekatan konseptual untuk menjelaskan dan mengaitkan dengan teori-teori yang relevan. Sumber data dalam penelitian ini menggunakan sumber data sekunder yang didapat dari literatur dan sumber hukum primer, sekunder, serta tersier. Hasil penelitian dianalisis dan diuraikan secara deskriptif kualitatif.

\section{Hasil Penelitian dan Pembahasan}

\section{Teori Restorative Justice}

\section{Restorative Justice dan Metode Penerapannya}

Keadilan restorative justice adalah suatu bentuk keadilan yang berpusat pada pemulihan terhadap korban, pelaku, dan masyarakat. Berbeda dengan keadilan restributif yang menfokuskan pada penghukuman terhadap pelaku, namun keadilan restoratif ini berfokus pada pemulihan terahadap korban, pelaku kejahatan serta masyarakat yang merasa dirugikan atas perbatan yang diperbuat oleh pelaku. Hal ini dikarenakan setiap kejahatan yang diperbuat, korbanlah yang

\footnotetext{
${ }^{5}$ Mahrus Ali, Dasar-Dasar Hukum Pidana, Cetakkan ke-empat, Sinar Grafika, Jakarta, 2017, hlm. 11-13.
} 
pertama-tama menderita akibat perbuatan yang diperbuat tersebut, baik menderita secara materill maupun secara immaterill, sedangkan pelaku merupakan orang yang haruslah dimintai pertangungjawaban atas suatu perbuatan yang dia perbuat serta masyarakat turut dipulihkan atas perbuatan yang diperbuat menimbulkan ketidakharmonisan yang timbul ditengah masyarakat. ${ }^{6}$

Restorative justice pada awalnya merupakan suatu alternatif penyelesaian tindak pidana yang dalam mekanisme tata peradilan pidana berfokus pada pemidanaan yang di ubah menjadi proses dialog dan mediasi dengan melibatkan pelaku, korban, keluarga pelaku, dan/atau keluarga korban dan pihak yang terkait. Dalam hal ini menciptakan kesepakatan atas penyelesaian pidana yang adil dan seimbang bagi korban maupun pelaku dengan mengedepankan pemulihan kembali pada keadaan semula dan mengembalikkan pola hubungan yang baik didalam masyarakat. Prinsip dasar dari keadilan restoratif ialah adanya pemulihan kepada korban yang menderita akibat kejahatan dan atau perbuatan yang merugikan bagi si korban dengan memberikan ganti rugi kepada korban, perdamaian, dan pelaku melakukan kerja-kerja sosial maupun kesepakatankesepakatan lainnya. Pada dasarnya hukum yang adil menurut restorative justice ini tentunta tidak berat sebelah, tidak memihak, dan pada hakikatnya memperlakukan dengan adil 7 .

a. Prinsip-Prinsip dasar restorative justice

1) Keadilan restoratif mengutamakan pemulihan atau restorasi bagi semua pihak yang terkena dampak dari tindak kejahatan yaitu korban, pelaku, dan masyarakat.

2) Keadilan restorative berfokus pada tiga kebutuhan pihak yakni: korban, pelaku, dan masyarakat

3) Keadilan restoratif memperhatikan kewajiban dan tangunggjawab yang muncul karena tindak kejahatan 8 .

b. Empat Pilar penting dalam restorative justice

1) Keadilan restoratif memandang bahwa terdapat jaringan di dalam kehidupan manusia, maka untuk memulihkan jaringan hubungan haruslah diadakan pertemuan bersama antara pihak-pihak yang terkait dalam hunungan tersebut.

2) Keadilan restoratif lebih menekankan pada pemulihan hubungan antara pelanggar dengan korban dan komunitasnya dengan kewajiban bagi si pelanggar hukum untuk memberikan kepada korban dan komunitas.

\footnotetext{
hlm. 27.

${ }^{6}$ Yoachim Agus Tridiatno, Keadilan Restoratif, Cetakkan Kelima, Cahaya Atma Pustaka, Yogyakarta, 2019, Lampiran Surat Keputusan Direktur Jendral Badan Peradilan Umum No 1691/DJU/SK/PS.00/12/2020. 22 Desember 2020 tentang Pedoman Penerapan Restorative Justice di Lingkungan Peradilan Umum, diakses pada 26 April 2021, pukul 12.00 WIB.

${ }^{8}$ Yoachim Agus Tridiatno, Op. Cit., hlm. 34-40
} 
3) Prinsip kolaborasi / kerjasama melalui pertemuan dan musyawarah yang sangat ditekankan untuk memulihkan hubungan antara pelanggar, korban dan komunitas diadakanlah yang namanya pertemuan antara pihak-pihak terkait.

4) Keadilan restoratif mementingkan nilai hormat pada setiap orang (respect), sikap hormat itulah yang ditunjukkan dengan adanya pertemuan dan dialog antara pihak-pihak terkait dan saling mendengarkan penjelasan antara satu dengan yang lain. ${ }^{9}$

c. Bentuk-bentuk restorative justice

Restorative justice memiliki beberapa bentuk yang diterapkan diberbagai negara diantaranya sebagai berikut :

1) Mediasi pelaku-korban (victim-offender mediation)

2) Pertemuan kelompok kelurga (family group conferencing)

3) Pertemuan restoratif (restorative conferencing)

4) Dewan peradilan masyarakat (commnity restorative boards)

5) Lingkaran restorative atau sistem restoratif (restorative circles or restorative systems. ${ }^{10}$

d. Penerapan restorative justice

Dewasa ini, apabila terjadi suatu tindak pidana masyarakat cenderung menggunakan jalur pengadilan yang secara konseptual dan teoritis akan menciptakan keadilan. Namun dalam kenyataannya, hal ini merupakan hal yang tidak mudah untuk dicapai. Hal ini disebabkan bahwa keadilan sebenarnya bersifat subjektif tergantung dari orang yang mendapatkan dan cara mengimplementasikan bentuk keadilan tersebut. Namun perlu disadari bahwa hasil yang akan dicapai dari proses penyelesaian perkara dengan jalur peradilan bersifat win-lose solution. Adanya sifat yang demikian akan terdapat pihak yang menang dan terdapat pula pihak yang kalah. Dengan kenyataan seperti ini, penyelesaian suatu perkara melalui jalur peradilan tradisional pada umumnya kerap menimbulkan satu rasa "tidak enak", menyimpan dendam, merasa tidak puas, merasa tidak adil bahkan lebih parah berniat ingin membalas dendam.

Munculnya konsep restorative justice bukan berarti meniadakan pidana penjara, dalam perkara-perkara tertentu yang menimbulkan kerugian secara massal dan berkaitan dengan berharga nyawa seseorang, maka pidana penjara masih dapat dipergunakan. Konsep restorative justice merupakan suatu konsep yang mampu berfungsi sebagai akselerator dari asas peradilan sederhana, cepat, dan biaya ringan, sehingga lebih menjamin terpenuhinya kepastian hukum dan keadilan masyarakat. ${ }^{11}$ Menurut pandangan konsep restorative justice, penanganan

\footnotetext{
${ }_{9}$ Ibid., hlm. 42-43.

10 Jonlar Purba, Penegakekan Hukum Terbadap Tindak Pidana Bermotif Ringan dengan Restorative Justice, Cetakan Pertama, Jala Permata Aksara, Jakarta, 2017, hlm. 63.

${ }^{11}$ Hanafi Arief dan Ningrum Ambarsari, "Penerapan Prinsip Restorative Justice dalam Sistem Peradilan Pidana di Indonesia”, Jurnal Al’Adl, Volume X Nomor 2, Juli 2018, hlm. 181.
} 
kejahatan yang terjadi bukan hanya menjadi tanggung jawab negara akan tetapi juga merupakan tanggung jawab masyarakat. Oleh karena itu konsep restorative justice di bangun berdasarkan pengertian bahwa kejahatan yang telah menimbulkan kerugian harus dipulihkan kembali baik kerugian yang di derita oleh korban maupun kerugian maupun yang di tanggung oleh masyarakat.

Keterlibatan anggota masyarakat sangat dibutuhkan untuk membantu memperbaiki kesalahan dan penyimpangan yang terjadi di sekitar lingkungan masyarakat yang bersangkutan. Pemberian penghargaan dan penghormatan pada korban dengan mewajibkan pihak pelaku melakukan pemulihan kembali atau akibat tindak pidana yang telah dilakukannya. Pemulihan yang dilakukan oleh pelaku bisa berupa ganti rugi, pekerjaan sosial atau melakukan sesuatu perbaikan atau kegiatan tertentu sesuai dengan keputusan bersama yang telah disepakati semua. ${ }^{12}$ Berikut bentuk penerapan restorative justice:

1) Mediasi pelaku-korban (victim-offender mediation)

2) Pertemuan kelompok kelurga (family group conferencing)

3) Pertemuan restoratif (restorative conferencing)

4) Dewan peradilan masyarakat (commnity restorative boards)

5) Lingkaran restorative atau sistem restoratif (restorative circles or restorative systems). ${ }^{13}$

\section{Model Restorative Justice Tingkat Penyidikan (Kepolisian), Penuntutan (Jaksa), dan Persidangan (Pengadilan)}

Berdasarkan uraian pembahasan di atas, penulis menggunakan analisis sintesis hukum yang mendasarkan bahwa UU ITE sebagaimana dalam perumusan awalnya ialah undang-undng yang bersifat administrasi bukan pemidanaan. Beberapa ahli hukum pernah mengemukakan bahwa undangundang ini memanglah undang-undang administrasi dan penetapan sanksi pemidanaan itu boleh diterapkan asalkan sesuai dengan koridor lapangan administrasi dan prinsip restorative justice sangatlah tepat untuk diterapkan semua semata-mata untuk menciptakan hukum yang damai sebagaimana yang dijelaskan dalam teori hukum tatanan hidup damai yang dikemukakan oleh St. Agustinus dalam bukunya Bernart menyatakan "bahwa hukum seharusnya menciptakan kedamaian dalam suatu tatanan hidup manusia, bukan sebaliknya menciptakan keributan dalam tatanan hidup masyarakat.

\section{a. Penyidikan}

Surat Edaran Nomor 8 Tahun 2018 tentang Pedoman Penerapan Keadilan Restoratif Dalam Penyelesaian Perkara Pidana sebagai berikut:

\footnotetext{
${ }^{12}$ Ibid., hlm. 182.

${ }^{13}$ Jonlar Purba, Op. Cit., hlm. 63
} 
a) Syarat Materil

1) Tidak menimbulkan keresahan masyarakat dan tidak ada penolakan masyarakat.

2) Tidak terdampak konflik sosial.

3) Adanya pernytaan dari semua pihak yang terlibat untuk tidak keberatan dan melepaskan hak menuntutnya dihadapan hukum.

b) Syarat Formil

1) Surat permohonan perdamaian kedua bela pihak (pelapor dan terlapor).

2) Surat pernyataan perdamaian (akte dading) dan penyelesaian perselisihan para pihak yang berperkara (pelapor, dan/atau keluarga pelapor, terlapor dan/atau keluarga terlapor dan perwakilan dan perwakilan dari tokoh masyarakat) diketahui oleh atasan penyidik.

3) Berita acara pemeriksaan tambahan pihak yang berperkara setelah dilakukan penyelesaian melalui keadilan restoratif.

4) Rekomendasi gelar perkara khusus yang menyetujui penyelesaian keadilan restoratif.

5) Pelaku tidak keberatan atas tangunggjawab ganti rugi atau dilakukan dengan sukarela.

6) Semua tindak pidana dapat dilakukan restorative justice terhadap kejahatan umum yang tidak menimbulkan korban manusia.

c) Mekanisme penerapan restorative justice

1) Setelah menerima permohonan permohonan perdamian kedua bela pihak (pelapor dan terlapor) yang ditandatangani diatas materai.

2) Setelah memenuhi syarat formil selanjutnya diajukan ke atasan penyidik untuk mendapatkan persetujuan.

3) Setelah mendapatkan persetujuan dari atasan kemudian ditetapkan waktu pelaksanaan penandatanganan pernyataan perdamaian.

4) Pelaksanaan konfrensi yang menghasilkan perjanjian kesepakatan yang ditandatangani oleh semua pihak yang terlibat.

5) Membuat nota dinas kepada pengawas penyidik atau kasatker perihal permohonan dilaksanakan gelar perkara khusus untuk tujuan penghentian perkara.

6) Menerbitkan surat perintah penghentian penyidikan/penyelidikkan dengan alasan restorative justice.

7) Surat penghentian penyidikan/penyelidikkan di tandatangani oleh Direktur Reserse Kriminal pada tingkat Mabes Polri, Direktur Reserse Kriminal pada tingkat Polda, dan Direktur Reserse Kriminal pada tingkat Polres atau Polsek

8) Mencatat pada buku register baru B-19 sebagai perkara keadilan restoratif (restorative justice) dihitung sebagai penyelesaian perkara. ${ }^{14}$

b. Penuntutan (jaksa)

Penuntutan sebagai subsistem dari sistem peradilan pidana memiliki posisi yang sangat strategi dalam hal penerapan restroratif justice ini,

${ }^{14}$ Surat Edaran (SE)/8/VII/2018 tentang Pedoman Penerapan Keadilan Restoratif Dalam Penyelesaian Perkara Pidana 
implementasi restroratif justice tersebut tentunya membutuhkan kreativitas kejaksaan (jaksa penuntut umum). Berikut alur penyelesaian kasus tindak pidana menggunakan upaya restorative justice pada tingkat penuntutan sebagaimana tertuang dalam Peraturan jaksa agung (PERJA) No. 15 Tahun 2020 tentang Penghentian Penuntutatn Berdasarkan Keadilan Restorative Justice:

a) Upaya Perdamaian terdapat dalam Pasal 7 dan Pasal 8 Peraturan Jaksa Agung Nomor 15 Tahun 2020 tentang Penghentian Penuntutn Berdasarkan Keadilan Restorative Justice

b) Proses Perdamaian terdapat dalam pasal 9 sampai dengan 14 Peraturan Jaksa Agung Nomor 15 Tahun 2020 tentang Penghentian Penuntutan Berdasarkan Keadilan Restorative Justice. ${ }^{15}$

c. Persidangan (Pengadilan)

Pemeriksaan sidang perkara pidana di Indonesia berdasarkan Kitab Undang-Undang Hukum Acara Pidana Nomor 8 Tahun 1981 (KUHP) memang tidak mendesain secara khusus proses penyelesaian perkara secara interpersonal, namun desain yang dibangun dalam sistem peradilan pidana di Indonesia yaitu pengadilan berfungsi untuk menentukkan tentang apakah hukum pidana telah dilanggar oleh seseorang ataukah tidak dan kalaupun dilanggar sanksi pemidanaan apakah yang dikenakan kepadanya dan kalaupun tidak dilanggar maka otomatis akan dibebaskan dari segala tuntutan. Berikut penerapan restorative justice pada pengadilan dapat dilihat berdasarkan Surat Keputusan Direktur Jendral Badan Peradilan Umum Nomor 1961/DJU/SK/PS.00/12/2020 tanggal 22 Desember 2020 tentang Pedoman Penerapan Restorative Justice di Lingkungan Peradilan Umum. ${ }^{16}$

\section{Penegakkan Hukum terhadap Pelaku dan Korban Undang-Undang Informasi dan Transaksi Elektronik Berbasis Restoratif Justice}

Dalam penerapan restorative justice, penulis menggunakan analisis sintesis hukum bahwa dalam penerapan prinsip restorative justice aparat penegak hukum harus paham tentang apa yang dinamakan dengan restorative justice ini dan metode penerapan seperti apa agar dalam penerapan sesuai dengan koridornya. Namun pada kenyataannya restorative justice ini sulit diterapkan secara maksimal yang menurut prespektif saya tidak sedikit oknum aparat penegak hukum tidak memahami adanya restorative justice, sehingga dalam praktiknya seharusnya hukum pidana yang seharusnya bersifat ultimum remidium berubah menjadi

15 Peraturan Jaksa Agung Nomor 15 Tahun 2020 tentang Penghentian Penuntutatn Berdasarkan Keadilan Restorative Justice (PERJA).

16 Lampiran Surat Keputusan Direktur Jendral Badan Peradilan Umum Nomor 1691/DJU/SK/PS.00/12/2020, 22 Desember 2020 tentang Pedoman Penerapan Restorative Justice di Lingkungan Peradilan Umum. 
primum remidium. Hukum seharusnya menciptakan keadilan (etis), kebahagian (utilitis), dan ketertiban (campuran) dalam bermasyarakat.

Sebelum membahas lebih lanjut, penulis akan menjelaskan tentang tindak pidana apa saja yang diatur dalam UU ITE. Pasal 27 sampai dengan Pasal 37 UU ITE tidak hanya mengatur tentang perbuatan-perbuatan yang dilarang, tetapi juga mengatur tentang sanksi pemidanaan. Ke semua aturan pemidanaan mulai dari Pasal 45 hingga Pasal 51 UU ITE. Berikut pasal-pasal yang mengatur tentang perbuatan yang dilarang, antara lain:

1) Pasal 27 ayat (1)

Setiap orang dengan sengaja dan tanpa hak mendistribusikan dan/atau mentransmisikan dan/atau membuat dapat diaksesnya Informasi Elektronik dan/atau Dokumen Elektronik yang memiliki muatan yang melanggar kesusilaan.

2) Pasal 27 ayat (2)

Setiap orang dengan sengaja dan tanpa hak mendistribusikan dan/atau mentransmisikan dan/atau membuat dapat diaksesnya Informasi Elektronik dan/atau Dokumen Elektronik yang memiliki muatan perjudian.

3) Pasal 27 ayat (3)

Setiap orang dengan sengaja dan tanpa hak mendistribusikan dan/atau mentransmisikan dan/atau membuat dapat diaksesnya Informasi Elektronik dan/atau Dokumen Elektronik yang memiliki muatan penghinaan dan/atau pencemaran nama baik.

4) Pasal 27 ayat (4)

Setiap orang dengan sengaja dan tanpa hak mendistribusikan dan/atau mentransmisikan dan/atau membuat dapat diaksesnya Informasi Elektronik dan/atau Dokumen Elektronik yang memiliki muatan pemerasan dan/atau pengancaman.

5) Pasal 28 ayat (1)

Setiap orang dengan sengaja dan tanpa hak menyebarkan berita bohong dan menyesatkan yang mengakibatkan kerugian konsumen dalam Transaksi Elektronik.

6) Pasal 28 ayat (2)

Setiap orang dengan sengaja dan tanpa hak menyebarkan informasi yang ditujukan untuk menimbulkan rasa kebencian atau permusuhan individu dan/atau kelompok masyarakat tertentu berdasarkan atas suku, agama, ras, dan antargolongan (SARA).

7) Pasal 29

Setiap orang dengan sengaja dan tanpa hak mengirimkan Informasi Elektronik dan/atau Dokumen Elektronik yang berisi ancaman kekerasan atau menakut-nakuti yang ditujukan secara pribadi.

8) Pasal 30 ayat (1)

Setiap orang dengan sengaja dan tanpa hak atau melawan hukum mengakses Komputer dan/atau Sistem Elektronik milik orang lain dengan cara apa pun. 
9) Pasal 30 ayat (2)

Setiap orang dengan sengaja dan tanpa hak atau melawan hukum mengakses Komputer dan/atau Sistem Elektronik dengan cara apa pun dengan tujuan untuk memperoleh Informasi Elektronik dan/atau Dokumen Elektronik.

10) Pasal 30 ayat (3)

Setiap orang dengan sengaja dan tanpa hak atau melawan hukum mengakses Komputer dan/atau Sistem Elektronik dengan cara apa pun dengan melanggar, menerobos, melampaui, atau menjebol sistem pengamanan.

11) Pasal 31 ayat (1)

Setiap orang dengan sengaja dan tanpa hak atau melawan hukum melakukan intersepsi atau penyadapan atas Informasi Elektronik dan/atau Dokumen Elektronik dalam suatu Komputer dan/atau Sistem Elektronik tertentu milik orang lain.

12) Pasal 31 ayat (2)

Setiap orang dengan sengaja dan tanpa hak atau melawan hukum melakukan intersepsi atas transmisi Informasi Elektronik dan/atau Dokumen Elektronik yang tidak bersifat publik dari, ke, dan di dalam suatu Komputer dan/atau Sistem Elektronik tertentu milik orang lain, baik yang tidak menyebabkan perubahan apa pun maupun yang menyebabkan adanya perubahan, penghilangan, dan/atau penghentian Informasi Elektronik dan/atau Dokumen Elektronik yang sedang ditransmisikan.

13) Pasal 31 ayat (3)

Kecuali intersepsi sebagaimana dimaksud pada ayat (1) dan ayat (2), intersepsi yang dilakukan dalam rangka penegakan hukum atas permintaan kepolisian, kejaksaan, dan/atau institusi penegak hukum lainnya yang ditetapkan berdasarkan undang-undang.

14) Pasal 31 ayat (4)

Ketentuan lebih lanjut mengenai tata cara intersepsi sebagaimana dimaksud pada ayat (3) diatur dengan Peraturan Pemerintah.

15) Pasal 32 ayat (1)

Setiap orang dengan sengaja dan tanpa hak atau melawan hukum dengan cara apa pun mengubah, menambah, mengurangi, melakukan transmisi, merusak, menghilangkan, memindahkan, menyembunyikan suatu Informasi Elektronik dan/atau Dokumen Elektronik milik orang lain atau milik publik.

16) Pasal 32 ayat (2)

Setiap orang dengan sengaja dan tanpa hak atau melawan hukum dengan cara apa pun memindahkan atau mentransfer Informasi Elektronik dan/atau Dokumen Elektronik kepada Sistem Elektronik orang lain yang tidak berhak.

17) Pasal 32 ayat (3)

Terhadap perbuatan sebagaimana dimaksud pada ayat (1) yang mengakibatkan terbukanya suatu Informasi Elektronik dan/atau 
Dokumen Elektronik yang bersifat rahasia menjadi dapat diakses oleh publik dengan keutuhan data yang tidak sebagaimana mestinya.

18) Pasal 33

Setiap orang dengan sengaja dan tanpa hak atau melawan hukum melakukan tindakan apa pun yang berakibat terganggunya Sistem Elektronik dan/atau mengakibatkan Sistem Elektronik menjadi tidak bekerja sebagaimana mestinya.

19) Pasal 35

Setiap orang dengan sengaja dan tanpa hak atau melawan hukum melakukan manipulasi, penciptaan, perubahan, penghilangan, pengrusakan Informasi Elektronik dan/atau Dokumen Elektronik dengan tujuan agar Informasi Elektronik dan/atau Dokumen Elektronik tersebut dianggap seolah-olah data yang otentik

20) Pasal 36

Setiap orang dengan sengaja dan tanpa hak atau melawan hukum melakukan perbuatan sebagaimana dimaksud dalam Pasal 27 sampai dengan Pasal 34 yang mengakibatkan kerugian bagi orang lain.

21) Pasal 37

Setiap orang dengan sengaja melakukan perbuatan yang dilarang sebagaimana dimaksud dalam Pasal 27 sampai dengan Pasal 36 di luar wilayah Indonesia terhadap Sistem Elektronik yang berada di wilayah yurisdiksi Indonesia.

Berdasarkan penjelasan di atas dapat dipahami bahwa UU ITE menjelaskan tentang perbuatan apa saja yang dilarang. Sementara beberapa penjelasan tentang perbuatan yang masuk dalam golongan tindak pidana informasi dan transaksi elektronik antara lain :

a) Yang memiliki muatan yang melanggar kesusilaan

b) Yang memiliki muatan perjudian

c) Yang memiliki muatan pencemaran nama baik

d) Yang memiliki muatan pemerasan

e) Yang menyebarkan berita bohong

f) Yang menyebarkan informasi kebencian SARA

g) Yang berisi ancaman kekerasan secara pribadi

h) Yang mengakses sistem elektronik orang lain

i) Yang menjebol sistem pengaman dari sistem elektronik

j) Yang melakukan penyadapan

k) Yang mengubah, menambah, mengurangi, melakukan transmisi, merusak, menghilangkan, memindahkan, menyembunyikan suatu informasi elektronik dan/atau dokumen elektronik

1) Yang memindahkan infomasi dan/atau dokumen elektronik ke orang lain

m) Yang mengakibatkan terbukanya informasi dan/atau dokumen elektronik yang bersifat rahasia menjadi dapat diakses oleh publik 
n) Yang berakibat terganggunya sistem elektronik yang melakukan manipulasi informasi dan/atau dokumen elektronik seolah-olah data yang otentik.

Kemudian, jika melihat uraian di atas pendekatan restorative justice pada pelaku dan korban Undang-Undang ITE dapat digunakan dengan beberapa metode :

a) Mediasi pelaku-korban (victim-offender mediation)

b) Pertemuan kelompok kelurga (family group conferencing)

c) Pertemuan restoratif (restorative conferencing)

d) Dewan peradilan masyarakat (commnity restorative boards)

e) Lingkaran restoratif atau sistem restoratif (restorative circles or restorative systems $)^{17}$

Bahwa dalam hal ini, peneliti menggunakan analisis gramatikal, yaitu penulis membandingkan antara pasal yang termuat dalam UU ITE tersebut merupakan pasal yang sanksinya yang lebih dikedepankan adalah sanksi administrasi, bukan sanksi pemidanaan. Hal ini menginggat bahwa hukum pidana menurut prespektif penulis merupakan ultimum remidium yaitu bahwa hukum pidana sebagai obat terakhir, bukan sebagai primum remidium atau senjata pertama saat dimulainya perkara pemidanaan. Penulis dengan tegas mengatakan bahwasanya pasal-pasal dalam UU ITE justru memiliki muatan administrasi lebih besar dibandingkan sanksi pemidanaan. Hemat kata penulis menawarkan 3 konsep baru yang dikemas dalam bentuk model yang harapan penulis dapat menyelesaikan polemik yang terjadi, antara lain:

a) Moro model

Model penerapan restorative justice ini melalui upaya ganti rugi berupa kerugian materil yang timbul atas suatu perbuatan dan kerugian immaterial berupa permintaan maaf kepada korban dan keluarga korban atas perbuatan yang dilakukan. Selain itu, permintaan maaf kepada keluarga pelaku yang atas perbuatan tersebut menimbulkan rasa malu serta memberikan pendampingan untuk memperbaiki psikis dan psikolog dari si korban.

b) Dats model

Merupakan model yang penulis tawarkan dengan memfokuskan pada perbaikan psikis dan psikolog dari si pelaku agar tidak mengulangi perbuatan dengan menginsyafi segala perbuatan yang diperbuat dan tidak mengulangi di kemudian hari dan bisa menjadi pribadi yang lebih baik lagi didalam bermasyarakat.

${ }^{17}$ Jonlar Purba, Op. Cit., hlm. 63. 
c) Virtual justice model

Model yang peneliti tawarkan yakni dengan penyelesaian persoalan berbasis virtual dengan memanfaatkan teknologi yang dimiliki guna menghemat biaya yang dikeluarkan antara kedua bela pihak, namun tentunya difasilitasi oleh aparat penegak hukum.

\section{Penutup}

\section{Kesimpulan}

Berdasarkan pemaparan hasil dari penelitian di atas, dapat disimpulkan bahwa pertama, di tingkat penyidikan restorative justice melalui materiil dan formil, tingkat penuntutan melalui proses dan upaya perdamaian dengan memperhatikan perangkat pendukung sidang. Kedua, tingkat pengadilan melalui aparat penegak hukum yang dapat memilah dan mendukung dalam upaya restorative justice, sehingga menghasilkan putusan hukum yang berkeadilan. Kedua, rekonseptual restorative justice dalam penegakan hukum UU ITE melalui moro konsep, dats konsep, dan virtual justice consept.

\section{Saran}

Saran ditujukkan kepada aparat penegak hukum agar mengedepankan prinsip restorative justice, sehingga hukum dapat memberikan ruang kedamaian, keadilan, kebahagiaan dan ketertiban dalam kehidupan bermasyarakat.

\section{Daftar Pustaka}

\section{Buku}

Ali, Mahrus, Dasar-Dasar Hukum Pidana, Cetakkan Keempat, Sinar Grafika, Jakarta, 2017.

Purba, Jonlar, Penegakkan Hukum Terhadap Tindak Pidana Bermotif Ringan Dengan Restorative Justice, Cetakkan Pertama, Jala Permata Aksara, Jakarta 2017.

Tridiatno, Agus dan Yoachim, Keadilan Restoratif, Cetakkan Kelima, Cahaya Atma Pustaka, Yogyakarta, 2019.

\section{Jurnal}

Febby Mutiara Nelson, "Due Process Model dan Restorative Justice Di Indonesia: Suatu Telaah Konseptual“, Jurnal Hukum Pidana \& Kriminologi, Volume 1, No. 1 Oktober 2020.

Hanafi Arief dan Ningrum Ambarsari, "Penerapan Prinsip Restorative Justice dalam Sistem Peradilan Pidana di Indonesia", Jurnal Al'Adl, Volume X Nomor 2, Juli 2018.

Mahrus Ali, "Overcriminalization dalam Perundang-Undangan di Indonesia", Jurnal Hukum Ius Quia Iustum, Vol. 25, No. 3, 2018. 


\section{Peraturan Perundang-Undangan}

Undang-Undang Nomor 8 Tahun 1981 tentang Kitab Undang-Undang Hukum Acara Pidana (KUHAP)

Undang-Undang Nomor 19 Tahun 2016 tentang Perubahan Atas Undang-Undang Nomor 11 Tahun 2008 tentang Informasi dan Transaksi Elektronik

Lampiran Surat Keputusan Direktur Jendral Badan Peradilan Umum Nomor 1691/DJU/SK/PS.00/12/2020, 22 desember 2020 tentang Pedoman Penerapan Restorative Justice di Lingkungan Peradilan Umum

Surat Edaran (SE)/8/VII/2018 tentang Pedoman Penerapan Keadilan Restoratif Dalam Penyelesaian Perkara Pidana

Peraturan Jaksa Agung Nomor 15 Tahun 2020 tentang Penghentian Penuntutan Berdasarkan Keadilan Restorative Justice

\section{Media Elektronik}

Detik.com, https://news.detik.com/berita/d-5374503/ditjen-pas-warga-binaan252384-orang-kapasitas-lapas-rutan-hanya-135704. 